\title{
Metabolic Changes in Salivary Glands of Rats under Glutamate-Induced Obesity
}

\author{
Tetyana V Beregova ${ }^{1 *}$, Tetyana M Falalyeyeva ${ }^{1}$, Karine S Neporada ${ }^{2}$ and Liudmyla P Gordienko ${ }^{2}$ \\ ${ }^{1}$ The Institute of Biology, Taras Shevchenko National University of Kyiv, Kyiv, Ukraine \\ Ukrainian Medical Dental Academy, Poltava, Ukraine
}

Received: September 08, 2014; Accepted: October 17, 2014; Published: October 23, 2014

*Corresponding author: Tetyana V Beregova, The Institute of Biology, Taras Shevcheno National University of Kyiv, Kyiv, Ukraine, Tel: +380-672-501498; E-mail: tberegova@mail.ru

\begin{abstract}
In the past two decades, the world has seen a sustained increase in obesity, and the levels of overweight and obese persons worldwide have reached epidemic proportions. It is well established that obesity induces all major metabolic disorders, especially diabetes, cardiovascular disease, hypertension, and fatty liver disease. Obesity is one of the urgent medical concerns that mainly associated with low physical activity, the growth of high caloric feeding as well as the uncontrolled use of food additives, especially monosodium glutamate. There is a close relation between obesity and oral health. Obesity is associated with hypo salivation and thereby related to several aspects of oral health. However, pathological mechanisms involved in the impact of obesity to salivary glands are not fully established. On experimental model of obesity induced by monosodium glutamate metabolic changes were studied in the tissues of salivary glands of rats. Administration of monosodium glutamate in the neonatal period leads to the development of obesity in four -month-old rats. Under monosodium glutamate - induced - obesity there are metabolic changes in salivary glands of rats such as marked elevation in the activity of NO-synthase and the maintenance of nitrites, significant decrease of activity of ornithine decarboxylase and $\alpha$-amylase, increasing activity of general proteinases and significant decreasing of general proteinases inhibitors maintenance, significant increase of oxidative modified proteins.
\end{abstract}

Conclusion: Under experimental obesity induced by monosodium glutamate pathological changes in salivary glands tissues appear such as intensification of free-radical oxidation, misbalance of proteolysis by decompensated type, decreased protein synthesis function, misbalance of polyamines and NO-ergic systems.

Keywords: Salivary glands; Obesity; Monosodium glutamate

\section{Introduction}

Metabolism is an essential process for the maintenance of life and homeostasis of the organism. Diseases associated with metabolic disorders such as hyperlipidemia, diabetes and obesity have become extremely common. Today, obesity becomes endemic. World Health Organization (WHO) has declared obesity a global epidemic and took it under control [1-3]. Epidemiology and animal models suggest that dietary Monosodium Glutamate (MSG) may contribute to the onset of obesity. Higher amounts of individual MSG consumption are associated with the risk of being overweight independent of other major determinants [4]. Monosodium glutamate is widely distributed and is naturally occurring in various foods. Obesogenic properties of monosodium glutamate were studied for decades. He K et al. [2] demonstrated that MSG intake may be associated with increased risk of overweight independent of physical activity and total energy intake in humans. Hirata et al. [5] demonstrated that MSG obese rats develop insulin resistance to peripheral glucose uptake. MSG induces hyperinsulinemia in three-month-old rats; the obesity of MSG animals is a metabolic alteration characterized by an enhanced adipocyte capacity to transport glucose and to synthesize lipids resulting in increased insulin sensitivity [6]. It was supposed that the central lesions produced by MSG treatment disrupt the regulation of the hypothalamic-pituitary-adrenal axis as the hyper functional state of adrenals revealed signs of MSGtreated rats [7]. However, information on the impact of obesity on oral health is sparse. Obesity is related to several aspects of oral health, such as caries, periodontitis and xerostomia $[8,9]$. Inoue et al. [10] reported that hypothalamic obesity was accompanied by the changes in salivary gland weight that were interpreted as decreased activity of the sympathetic nervous system following Ventromedial Hypothalamic (VMH) lessions. Modeer $\mathrm{T}$ et al. [11] demonstrated that childhood obesity is associated with reduced flow rate of stimulated whole saliva and dental caries and further strengthens obesity's negative effect on children's oral health. Mozaffari et al. [12] reported that obesity promotes pro-inflammatory changes within the sub-mandibular gland, without affecting glandular architecture. We could not find any information on the investigation of metabolic changes of salivary glands using MSG-obesity model. This is the first study that has examined the impact of salivary glands using MSG-obesity model. The aim of the study was to investigate metabolic changes in salivary glands under MSG-induced obesity.

\section{Methods}

The study was carried out on 20 white rats that were divided on 2 groups. Group I was intact control (4-month old rats). Newborns rats of intact group were administered with saline subcutaneously in the volume of $8 \mu \mathrm{l} / \mathrm{g}$ at second, fourth, sixth, eighth and tenth postnatal days. Newborn rats of Group II were administered with monosodium glutamate at a dose $4 \mathrm{mg} / \mathrm{g}$ of 
body weight subcutaneously on the second, fourth, sixth, eighth and tenth day of life [13]. Within 4 months after birth, rats were on a standard diet. The changes in body weight in all groups of rats were analyzed for 4 months from birth. Four-month-aged animals were sacrificed. Body Mass Index (BMI) (the ratio of body weight $(\mathrm{g})$ of rats to the square of the body length $\left(\mathrm{cm}^{2}\right)$ ) was calculated. Salivary glands were homogenized. In the homogenate of salivary glands we determined the activity of NO- synthase and the maintenance of nitrites [14], Ornithine Decarboxylase (ODC) [15], $\alpha$-amylase [16], general proteinases [17], inhibitors of the general proteinases [18], oxidative modified proteins [19]. Statistical analysis of data was carried out using Student's t test.

Research was conducted in compliance with the standards of the Convention on Bioethics of the Council of Europe's 'Europe Convention for the Protection of Vertebrate Animals' used for experimental and other scientific purposes' (1997), the general ethical principles of animal experiments, approved by the First National Congress on Bioethics Ukraine (September 2001) and other international agreements and national legislation in this field. Animals were kept in a vivarium that was accredited in accordance with the standard rules on ordering, equipment and maintenance of experimental biological clinics (vivarium). Instruments to be used for research are subject to metrological control.

\section{Results}

Administration of MSG in the neonatal period leads to the development of obesity in 4-month-old rats. It was established that BMI of control rats was $(0.57 \pm 0.02) \mathrm{g} / \mathrm{cm}^{2}$. After 4 months in animals injected with MSG, BMI was significantly higher in comparison with control animals by $21 \%\left((0.69 \pm 0.03) \mathrm{g} / \mathrm{cm}^{2}\right.$, $p<0.05$ ). The calculation of BMI suggested the development of obesity in group II.

We determined that under monosodium glutamate-induced obesity the activity of NO- synthase was 1.92 times greater ( $p<$ 0.05 ) and the maintenance of nitrites was 1.53 times greater ( $p$ $<0.05)$ than control group. It was found significant decreasing of ODC activity by 1.3 times $(p<0.05)$ and $\alpha$-amylase by 1.27 times $(p<0.05)$, increasing activity of general proteinases in 1.32

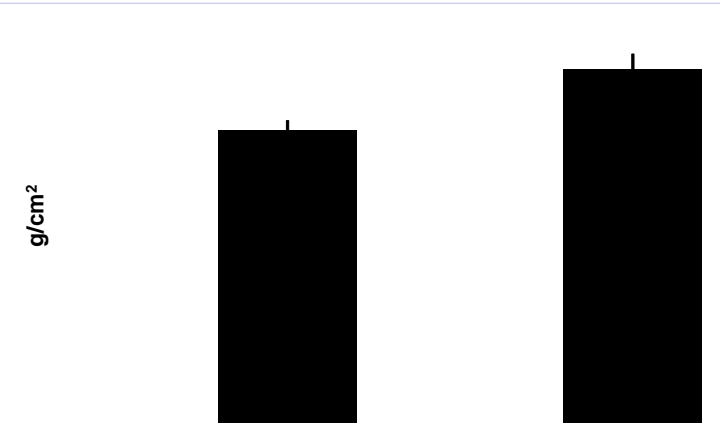

Figure 1: Body mass index under monosodium glutamate induced obesity, $(\mathrm{M} \pm \mathrm{m}): 1$ - intact rats, 2 - monosodium glutamate obesity. * - P $1-2<0.05$
Table 1: Metabolic changes in tissues of salivary glands under monosodium glutamate induced obesity, $(M \pm \mathrm{m})$.

\begin{tabular}{|c|c|c|c|}
\hline $\begin{array}{c}\text { Group of animals } \\
\text { Methods }\end{array}$ & $\begin{array}{c}\text { Obesity group } \\
(\boldsymbol{n}=\mathbf{1 1})\end{array}$ & $\begin{array}{c}\text { Control group } \\
(\boldsymbol{n}=\mathbf{9})\end{array}$ & $P_{1-2}<0.05$ \\
\hline $\begin{array}{c}\text { The activity of } \\
\text { NO- synthase, } \\
\mu \text { mol/g*min }\end{array}$ & $9.93 \pm 0.53$ & $5.18 \pm 0.56$ & $P_{1-2}<0.05$ \\
\hline $\begin{array}{c}\text { Content of the } \\
\text { nitrites, } \mu \text { mol/g }\end{array}$ & $0.072 \pm 0.002$ & $0.047 \pm 0.001$ & $P_{1-2}<0.05$ \\
\hline $\begin{array}{c}\text { The activity of or- } \\
\text { nithinedecarboxyl- } \\
\text { ase, nmol/g*min }\end{array}$ & $283.89 \pm 6.51$ & $369.75 \pm 12.36$ & $P_{1-2}<0.05$ \\
\hline $\begin{array}{c}\text { The activity of } \\
\alpha \text {-amylase, mg/ } \\
\text { g*min }\end{array}$ & $66.12 \pm 0.76$ & $83.90 \pm 1.36$ & $P_{1-2}<0.05$ \\
\hline $\begin{array}{c}\text { The activity } \\
\text { of general } \\
\text { proteinases, } \mu \mathrm{mol} / \\
\text { g*min }\end{array}$ & $0.62 \pm 0.01$ & $0.47 \pm 0.01$ & $P_{1-2}<0.05$ \\
\hline $\begin{array}{c}\text { Content of } \\
\text { the general } \\
\text { proteinases } \\
\text { ingibitors, g/kg }\end{array}$ & $34.62 \pm 0.64$ & $42.87 \pm 0.77$ & 0.05 \\
\hline $\begin{array}{c}\text { Content of the } \\
\text { oxidative modified } \\
\text { proteins, c.u. }\end{array}$ & $0.23 \pm 0.01$ & $0.16 \pm 0.01$ & \\
\hline
\end{tabular}

times $(p<0.05)$ and significant decreasing of general proteinases inhibitors maintenance in 1.24 times $(p<0.05)$, compared with the control group. There is significant increasing of oxidative modified proteins in 1.44 times $(p<0.05)$ in the tissues of salivary glands of rats compared with the control group.

\section{Discussion}

Imbalance of Nitric Oxide (NO) production is important in the development of pathological changes in obesity [20]. In the present study we clearly demonstrated the marked elevation in the activity of NO-synthase and the maintenance of nitrites. Excessive production of NO contributes to the formation of peroxynitrite which interacts with lipids, DNA, and proteins via direct oxidative reactions or via indirect, radical-mediated mechanisms. These reactions trigger cellular responses ranging from subtle modulations of cell signaling to overwhelming oxidative injury, committing cells to necrosis or apoptosis.

Salivary $\alpha$-amylase is a key enzyme that carries digestive function and hydrolyzes $\alpha$-1,4-glycosidic bonds in the molecules of amylose, amylopectin, glycogen resulting in formation of dextrins, maltose and isomaltose. It is known that the secretion of $\alpha$-amylase by salivary glands is regulated by the autonomic nervous system. Stimulation of beta-adrenergic receptors plays a major role in the regulation of $\alpha$-amylase secretion [21]. Thus, the decrease in activity of $\alpha$-amylase can be measured as an indicator of inhibition of protein synthesis in the salivary glands of rats under the influence of MSG-induced obesity.

Cell growth and differentiation require the presence of optimal concentrations of polyamines. ODC is a key regulatory enzyme of polyamines synthesis such as putrescine, spermine, spermidine and others that regulate processes of replication and 
transcription and, consequently, cell proliferation. The essential role of polyamines is the initiation of peptide synthesis by changing the conformation of the ribosomes. Thus, polyamines play an important regulatory role in processes related to the biosynthesis of proteins and nucleic acids [22]. There are data on the role of polyamines associated with the mechanism of action ODC to the Epidermal Growth Factor (EGF). Serrero et al [23]. found that in genetically obese ob/ob mice there are reduced levels of EGF in submandibular salivary glands and blood plasma compared to control animals. We demonstrated decreased activity of ODC in salivary gland tissues of rats under MSGinduced obesity. Thus, monosodium glutamate-induced model of obesity leads to decreased activity of ODC and $\alpha$-amylase. It shows that there is inhibition of the synthesis of regulatory polyamines, nucleic acids and proteins in the tissues of the salivary glands of rats under glutamate-induced obesity.

Excessive activation of proteolysis is dangerous for protein structures and tissues and causes the development of destructive and inflammatory changes, allergic reactions, disturbance of hemostasis and is one of the factors contributing to invasion of cancer cells. An objective assessment of proteolysis system is possible only if taking into account the total proteolytic activity of the investigated substrate and activity of proteinase inhibitors that inhibit proteolytic enzymes [18]. In the present study it was established the increasing activity of general proteinases and significant decreasing of general proteinases inhibitors maintenance. Thus, there is misbalance of proteolysis by decompensated type.

Systemic oxidative stress is one of key factors in the pathogenesis of obesity-related diseases [24]. Carbonylation of proteins is one of the markers of oxidative stress. Inactivation of enzymes and hypersensitivity of modified proteins to proteolysis are the most important consequences of oxidative modification of proteins. It was established that there is significant increasing of oxidative modified proteins in the tissues of salivary glands of rats compared with the control group.

Thus, under monosodium glutamate-induced- obesity pathological changes in salivary glands tissues of rats appear such as intensification of free-radical oxidation, misbalance of proteolysis by decompensated type, decreased activity of $\alpha$-amylase, misbalance of polyamines and NO-ergic system. We are planning further studies that are necessary to translate model data of pathological changes in salivary glands to human population as well conduction of epidemiological studies for obtaining evidence regarding adverse effect of particular food additives.

\section{Conclusions}

1. The introduction of monosodium glutamate to newborn rats causes obesity in adulthood.

2. Under monosodium glutamate-induced - obesity there is marked elevation in the activity of NO-synthase and the maintenance of nitrites indicating the activation of NOergic system of salivary glands of rats.
3. Under monosodium glutamate-induced - obesity protein synthesis function of salivary glands is decreased as evidenced by significant decrease of activity of ODC and $\alpha$-amylase.

4. Under monosodium glutamate-induced - obesity proteinase inhibitor balance of salivary glands changed by decompensated type as evidenced by significant increasing activity of general proteinases and significant decreasing of general proteinases inhibitors maintenance.

5. Under monosodium glutamate-induced - obesity there is intensification of free-radical oxidation in the tissues of salivary glands as evidenced by significant increasing of oxidative modified proteins.

\section{References}

1. Farooqi SI. Genetic, molecular and physiological insights into human obesity. Eur J Clin Invest. 2011; 41(4): 451-5. doi: 10.1111/j.13652362.2010.02468.x

2. He K, Zhao L, Daviglus ML, Dyer AR, Van Horn L, Garside D, et al. Association of monosodium glutamate intake with overweight in Chinese adults: the INTERMAP. Obesity (Silver Spring). 2008;16(8):1875-80. doi: 10.1038/oby.2008.274.

3. Singla P, Bardoloi A, Parkash A. Metabolic effects of obesity: a review. World J Diabetes. 2010; 1(3): 76-88. Doi: 10.4239/wjd.v1.i3.76.

4. Insawang $\mathrm{T}$, Selmi $\mathrm{C}$, Cha'on $\mathrm{U}$, Pethlert $\mathrm{S}$, Yongvanit $\mathrm{P}$, Areejitranusorn $\mathrm{P}$, et al. Monosodium glutamate (MSG) intake is associated with the prevalence of metabolic syndrome in a rural Thai population. Nutr Metab (Lond). 2012; 9(1): 50. doi: 10.1186/1743-7075-9-50.

5. Hirata AE, Andrade IS, Vaskevicius P, Dolnikoff MS. Monosodium glutamate (MSG)-obese rats develop glucose intolerance and insulin resistance to peripheral glucose uptake. Braz J Med Biol Res. 1997; 30 (5), 671-4.

6. Marmo MR, Dolnikoff MS, Kettelhut IC, Matsushita DM, Hell NS, Lima FB. Neonatal monosodium glutamate treatment increases epididymal adipose tissue sensitivity to insulin in three-month old rats. Braz J Med Biol Res. 1994; 27(5): 1249-53.

7. Dolnikoff MS, Kater CE, Egami M, de Andrade IS, Marmo MR. Neonatal treatment with monosodium glutamate increases plasma corticosterone in the rat. Neuroendocrinology. 1988; 48(6): 645-49.

8. Flink H, Bergdahl M, Tegelberg A, Rosenblad A, Lagerlof F. Prevalence of hyposalivation in relation to general health, body mass index and remaining teeth in different age groups of adults. Community Dent Oral Epidemiol. 2008; 36(6): 523-31. doi: 10.1111/j.16000528.2008.00432.x.

9. Ueda H, Yagi T, Amitani H, Asakawa A, Ikeda S, Mlyawaki S, et al. The roles of salivary secretion, brain-gut peptides, and oral hygiene in obesity. Obes Res Clin Pract. 2013; 7(5): 321-29. Doi: 10.1016/j. orcp.2013.05.001.

10. Inoue S, Campfield LA, Bray GA. Comparison of metabolic alterations in hypothalamic and high fat diet-induced obesity. Am J Physiol. 1977; 233(3): R162-8.

11. Modeer T, Blomberg C, Wondimu B, Julihn A, Marcus C. Association between obesity, flow rate of saliva, and dental caries in adolescents. Obesity (Silver Spring). 2010; 18(12):2367-73. doi: 10.1038/ oby.2010.63. 
12. Mozaffari MS, Abdelsayed R, Zakhary I, El-Salanty M, Liu JY, Wimborne H. Submandibular gland and caries susceptibility in the obese Zucker rat. J Oral Pathol Med. 2011; 40(2): 194-200. doi: 10.1111/j.16000714.2010.00965.x.

13. Miskowiak B \& Partyka M. Effects of neonatal treatment with MSG (monosodium glutamate) on hypothalamo-pituitary-thyroid axis in adult male rats. Histol Histopathol.1993; 8(4): 731-4.

14. Hevel JM. Purification of the inducible murene machrophage nitric oxide synthase. J Biol Chem. 1991; 266(34): 22789-91.

15. Khramov VA. Simple method for determining the activity of ornithine decarboxylase in a mixed human saliva. Clin Lab Diagnostics. 1997; 4: 14-15. [Russian]

16. Menshikov VV, Delektorskaya LN, Zolotinskaya RP, et al. Laboratory Methods in the clinic. Moscow: Medicine. 1987.[Russian]

17. Ugolev AM, \& Iezuitova NN, \& Masevich HS, et al. Study of the digestive tract in humans. Saint Petersburg: Science. 1969.[Russian]

18. Veremeyenko KN, Goloborodko OP, Kizim AI. Proteolysis in normal and pathological conditions. Kiev: Health. 1988.[Russian]

19. Dubinina EE \& Burmistrov SO. Oxidative modification of proteins of human serum. Method of determining. Questions of medicinal chemistry. 1995; 1: 24-26. [Russian]

20. Codoñer-Franch P, Tavárez-Alonso S, Murria-Estal R, Megías-Vericat J, Tortajada-Girbés M, Alonso-Iglesias E. Nitric oxide production is increased in severely obese children and related to markers of oxidative stress and inflammation. Atherosclerosis. 2011; 215(2): 475-80. doi: 10.1016/j.atherosclerosis.2010.12.035.

21. Nater UM, Rohleder N. Salivary alpha amylase as a non-invasive biomarker for the sympathetic nervous system: current state of research. Psychoneuroendocrinology. 2009; 34(4): 486-96. doi: 10.1016/j.psyneuen.2009.01.014.

22. Pegg AE. Regulation of ornithine decarboxylase. Journal of Biological Chemistry. 2006; 281(21): 14529-32.

23. Serrero G, Lepak NM, Hayashi J, Goodrich SP. Impaired epidermal growth factor production in genetically obese ob/ob mice. Am J Physiol. 1993; 264(5 Pt 1): E 800-3.

24. Savini I, Catani MV, Evangelista D, Gasperi V, Avigliano L. Obesityassociated oxidative stress: strategies finalized to improve redox state. Int J Mol Sci. 2013; 14(5): 10497-538. doi: 10.3390/ijms140510497. 